\title{
To Analyze the Cost Structure of Different Cropping System in Indore (M. P.) India
}

\author{
Veena Rathore ${ }^{1}$, Harkesh Kumar Balai ${ }^{1 *}$ and S.K. Jain ${ }^{2}$ \\ ${ }^{1}$ College of Agriculture, Indore (COA), India \\ ${ }^{2}$ Agricultural Economics \& Farm Management, COA, Indore, India \\ *Corresponding author
}

\begin{abstract}
A B S T R A C T
Keywords

Crpping system, Cost structure, Small farmers,

Medium farmers, Large farmers

Article Info

Accepted:

24 June 2018

Available Online:

10 July 2018

It is revealed that the average Cost $\mathrm{C}_{3}$ of soybean cultivation was found to be Rs.37674 per hectare. Cost $\mathrm{C}_{3}$ was found to nominally decrease with increase size of holding due to economic of size of holding in input utilization. The average Cost $\mathrm{C}_{3}$ of wheat cultivation was found to be Rs.37739 per hectare. Cost $C_{3}$ was found to nominally increase with increase in size of holding it was due to higher use of purchased inputs by large size of holding. The average Cost $\mathrm{C}_{3}$ of gram cultivation was found to be Rs.36623 per hectare. Cost $\mathrm{C}_{3}$ was found to nominally increase with increase in size of holding it was due to higher use of yield attributing inputs by large size of holding. In nut shell, on the basis of data analysis on cost of cultivation of different cropping system, it can be concluded that the overall cost of cultivation on per hectare basis of the soybean-wheat cropping system was found to be higher. Cost $\mathrm{C}_{3}$ incurred in soybean-wheat cropping system was found to be Rs.75413 per hectare. On the other hand, the cost $\mathrm{C}_{3}$ incurred in soybean-gram cropping system was found to be Rs.74297 per hectare. It shows that Cost $\mathrm{C}_{3}$ was higher Rs.1116 per hectare in soybean-wheat cultivation over to soybean-gram cultivation.
\end{abstract}

\section{Introduction}

Cropping system is an important component of a farming system. It represents cropping patterns used in a farm and their interaction with farm resources, other farm enterprises and availab0le technology which determine their makeup. Cropping system specially intercropping and mixed cropping are receiving greater emphasis in Indian agriculture now, because stabilized yield advantage, especially under adverse weather condition, mixed and intercropping systems have built mechanism of risk bearing against environmental hazards.

Proper and well adopted cropping system increase supply of balanced food, feed and cash needs of marginal farmers, without extra expense. Experimental evidences have also proved that yield stability and monetary return is greater with intercropping and mixed cropping than single crop.

The Recently, huge gap between existing cropping systems and improved cropping 
systems, improved cropping systems are capable to increase the farmers land use efficiency, productivity and economic return with respect to farmers land use efficiency; productivity and economic return in respect to existing cropping systems. So this study was chosen for calculating economies of production of different cropping systems. The specific objectives of study were as below:

\section{Materials and Methods}

\section{Study area}

Indore district, a progressive agricultural area, was selected for present study due to higher changing cropping system. In Indore district Depalpur block was selected purposively for the study as more cropping pattern appear in this block.

\section{Sampling procedure}

Multi stage sampling technique was used for drawing a sample for the present study. In the first stage, the villages were selected for study. At the second stage of sampling, the farmers were selected for data collection as respondents of study.

\section{Selection of villages}

A list of all the villages in the selected block where cropping systems were implemented was prepared with the help of Department of Agriculture Indore. From this list 5 villages were selected randomly.

\section{Selection of respondents}

List of farmers of the selected villages was prepared. In the third stage of selection 70 farmers were selected randomly by proportional allocation of 3 categories i.e. small (less than 2 ha), medium (2 to 4 ha.) and large (more than 4 ha.). Thus 70 farmers was the sample of present study (Table 1).

\section{Cost concepts}

The cost of cultivation classified as recommended by, "Special expert committee on cost estimates, GOI, New Delhi", was used in this study. The cost concepts are given below:

Cost $\mathbf{A}_{1:}$ It includes: -

Value of hired human labour,

Value of hired and owned bullock labour, Value of hired and owned machinery labour,

Value of owned and purchased seed, Value of fertilizers, manures and chemical,

Value of insecticide and pesticides,

Expenditure on irrigation,

Land revenue and taxes,

Interest paid on crop loan if taken,

Depreciation on farm assets excluding land,

Interest on working capital, Miscellaneous expenses.

$\operatorname{Cost} \mathbf{A}_{2}$ : It includes-

Cost $A_{1}+$ rent paid for leased in land

Cost $\mathrm{B}_{1}$ : It includes-

Cost $A_{2}+$ interest on value of owned fixed capital assets. (Excluding land)

Cost $\mathbf{B}_{2}$ : It includes-

Cost $\mathrm{B}_{1}+$ rental value of owned land

$\operatorname{Cost} \mathbf{C}_{1}$ : It includes-

Cost $\mathrm{B}_{1}+$ imputed value of family labour

Cost $\mathbf{C}_{2}$ : It includes-

Cost $\mathrm{B}_{2}$ +imputed value of family labour

Cost $\mathbf{C}_{3}$ : Cost $\mathrm{C}_{2}+10$ percent of cost $\mathrm{C}_{2}$ to account for managerial input of the farmer. 


\section{Evaluation of farm inputs}

Methods followed in evaluating different farm input for the present study are described in the following paragraphs.

\section{Hired_human_labour}

The farmers normally engage permanent farm labour on the basis of yearly wages and casual labour on daily wage basis for performing farm operations.

The casual labour was evaluated on the basis of actual wages prevailed in the locality.

The wages of male and female labour included payment given both in cash or kind. The value of kind components given to the labour was calculated at their prevailing market prices.

\section{Family labour}

The family labour cost was evaluated at the rate of prevailing wage rates in the locality for casual hired labour at various stages of operations.

\section{Bullock and machinery labour}

Estimation of bullock and machine labour charges on actual wages prevailed in the locality were considered.

For estimation of depreciation, interest on working capital, interest on fixed capital and rental value of owned land, following standard norms were used.

\section{Depreciation on farm assets}

The straight-line method was used for calculating rate of depreciation @ 10 per cent of assets value excluding land on per unit area basis.

\section{Interest on working capital}

It was worked out @ 12.50 percent for half of the duration of the crop.

\section{Interest on fixed capital}

Interest was charged @ 10 percent per annum on the value of implements, machineries, farm building, and irrigation structure and draft animals. It excludes interest on land input, because rental value of owned land is calculated separately.

\section{Rental value of owned land}

It was calculated on the basis of 25 percent $(1 / 4)$ of the gross income or prevalent rate in the area for the same.

\section{Return concepts}

\section{Value of farm produce}

This included the value of main product and the byproduct of the crop. The harvest price of the crop was considered for calculating the value of main produce. The value of by product was calculated at the prevailing price in the locality.

\section{Profitability}

For the estimation of profitability from cultivation of crops, the following profit efficiency measures were used in this study:

Gross income: It is defined as: total value of main product +by product.

Net farm income: It is defined as: gross income - cost ' $\mathrm{C}_{3}$ '

Family labour income: it is defined as: gross income- cost ' $\mathrm{B}_{2}$ '

Farm business income: It is the gross value of output at farm harvest prices (Main product +by product) - cost ' $\mathrm{A}_{1}$ ' 


$$
\begin{aligned}
& \text { B.C. ratio: } \\
& \text { B.C. ratio }=\frac{\text { Gross income }}{\text { Cost of cultivation }}
\end{aligned}
$$

\section{Results and Discussion}

Cost of cultivation of crops per hectare of existing cropping systems

A study on economics of cultivation of different cropping system prevailing in area is pertinent to find out their profitability in order to choose best alternative resources, cultivation practices and scale of production etc. Secondly, it gives an estimate of the amount, the farmers would require for cultivating as per size of crop area with different level of technological adoption. It is a well known fact that profitability of crop production depends upon the cost of production, yield per unit of area and their relative market prices. Hence, to determine the profitability from prevailing cropping system, the cost of cultivation on cost concept basis of crops was determined.

\section{Soybean}

The detail of cost of cultivation of soybean according to different size group has been presented in Table 2.

On the basis of different cost concepts, the cost of cultivation of soybean under prevailing cropping system per hectare on sample holding determined that on an average the cost of soybean (Cost $A_{1}$, operational cost) was found to Rs.18792 per hectare. The highest Cost $A_{1}$ of soybean cultivation was found to be Rs.19294 per hectare in large size of holding followed by Rs.18781 per hectare in medium size of holding and Rs.18300 per hectare in small size of holding. This indicated that cost $A_{1}$ increased with increase in size of holding. Similar finding were reported by Ahmed and Tanveer (2006). The cost $A_{1}$ which is the actual farm investment made by farmers is more important in analysis of cost of cultivation. Cost $\mathrm{A}_{2}$ was not considered in the study because farmers cultivated their own land.

The total cost estimates i.e. cost $\mathrm{C}_{1}, \mathrm{C}_{2}$ and $\mathrm{C}_{3}$ based on the imputed values of family labour would give an unrealistic and even misleading picture of costs. It is attributed to the fact that farmers try to minimize only out of pocket expenses of cultivation and that by and large, they make maximum use of resources they own, but it is also not justifiable to take into account only paid out costs. To determine the cost structure cost $\mathrm{C}_{1}, \mathrm{C}_{2}$ and $\mathrm{C}_{3}$ were also analyzed in the present study.

It is revealed that the average Cost $C_{3}$ of soybean cultivation was found to be Rs.37674 per hectare. Cost $\mathrm{C}_{3}$ was found to nominal by decrease with increase in size of holding due to economic of size of holding in input utilization Similar finding were reported by Pandey et al., (2009). The highest Cost $\mathrm{C}_{3}$ in soybean cultivation was found to be Rs.37992 per hectare in small size of holding followed by Rs.37805 per hectare in medium size of holding and Rs.37226 per hectare in large size of holding respectively.

\section{Wheat}

The detail of cost of cultivation of wheat according to different size group has been presented in Table 3.

On the basis of different cost concepts, the cost of cultivation of wheat under prevailing cropping system per hectare on sample holding determined that on an average the cost of wheat (Cost $A_{1}$, operational cost) was found to be Rs.19851 per hectare. The highest Cost $A_{1}$ of wheat cultivation was found to be Rs.21309 per hectare in large size of holding followed by Rs.19734 per hectare in medium 
size of holding and Rs.18509 per hectare in small size of holding. It was found that the cost $A_{1}$ increase with increase in size of holding. Similar finding were reported by Ahmed and Tanveer (2006).

It is revealed that the average Cost $\mathrm{C}_{3}$ of wheat cultivation was found to be Rs.37739 per hectare. Cost $\mathrm{C}_{3}$ was found to nominal by increase with increase in size of holding due to higher use of purchased inputs by large size of holding Similar finding were reported by Pandey et al., (2009). The highest Cost $\mathrm{C}_{3}$ in wheat cultivation was found to be Rs.39002 per hectare in large size of holding followed by Rs.37313 per hectare in medium size of holding and Rs.36902 per hectare in small size of holding respectively.

\section{Gram}

The detail of cost of cultivation of gram according to different size group has been presented in Table 4.

On the basis of different cost concepts, the cost of cultivation of gram under prevailing cropping system per hectare on sample holding determined that on an average the cost of gram (Cost $A_{1}$, operational cost) was found to be Rs.18702 per hectare. The highest Cost $A_{1}$ of gram cultivation was found to be Rs.21104 per hectare in large size of holding followed by Rs.19566 per hectare in medium size of holding and Rs.15437 per hectare in small size of holding. It was found that the cost $A_{1}$ increase with increase in size of holding Similar finding were reported by Biradar and Rajkumar (2007).

It is revealed that the average Cost $\mathrm{C}_{3}$ of gram cultivation was found to be Rs.36623 per hectare. Cost $\mathrm{C}_{3}$ was found to nominal by increase with increase in size of holding due to higher use of yield attributing inputs by large size of holding Similar finding were reported by Pandey et al., (2009). The highest Cost $\mathrm{C}_{3}$ in gram cultivation was found to be Rs.38118 per hectare in large size of holding followed by Rs.37349 per hectare in medium size of holding and Rs.34403 per hectare in small size of holding respectively.

\section{Cost of cultivation of different cropping system}

The detail cost as per cost concepts of different cropping systems has been presented in Table 5.

As already discussed, the main cropping systems of the area are: soybean-wheat and soybean-gram. The cost of cultivation of different cropping system on per hectare basis was found to vary depending upon the cost components and different combination for cropping systems.

Data shows that cost $A_{1}$ which may be treated as operation cost is important for economist and farmers also because it is determined as paid out cost from pocket. The operational cost i.e. cost $A_{1}$ incurred in soybean-wheat cropping system was found to be Rs.38643 per hectare. On the other hand, the cost $\mathrm{A}_{1}$ incurred in soybean-gram cropping system was found to be Rs.37494 per hectare. It shows that Cost $A_{1}$ was higher Rs.1149 per hectare in soybean-wheat cultivation over to soybean-gram cultivation. Similar finding were reported by Chauhan (2008).

It is noted that the operational cost incurred in seed + seed treatment and plant protection method in soybean-gram cropping system was found to be higher than soybean-wheat cropping system. The excess of cost incurred in seed and seed treatment (Rs.1471 /ha.) in soybean-gram cropping system might be due to higher market price of gram in comparison to wheat. Similarly the expenditure on plant protection measure in gram crop was due to higher damage of crop due to insect. 
Table.1 Allocation of farmers under study (Number)

\begin{tabular}{|c|c|c|c|}
\hline S.No. & Size group & Total number of farmers & Total selected farmers (n) \\
\hline $\mathbf{1 .}$ & Small farmers & 100 & $\mathbf{2 0}$ \\
\hline $\mathbf{2 .}$ & Medium farmers & 160 & $\mathbf{3 2}$ \\
\hline $\mathbf{3 .}$ & Large farmers & 90 & $\mathbf{1 8}$ \\
\hline $\mathbf{4 .}$ & Total & $\mathbf{3 5 0}$ & $\mathbf{7 0}$ \\
\hline
\end{tabular}

Table.2 Cost of cultivation of soybean per hectare of existing cropping systems according to their size group (Rs/ha)

\begin{tabular}{|c|c|c|c|c|c|}
\hline \multirow[t]{2}{*}{ S.No. } & \multirow[t]{2}{*}{ Cost practices } & \multicolumn{4}{|c|}{ Size group (Soybean) } \\
\hline & & Small & Medium & Large & Average \\
\hline 1. & Hired human labour & 2600 & 2800 & 4000 & 3133 \\
\hline 2. & Bullock labour & 1050 & 1750 & 1050 & 1283 \\
\hline 3. & Machine power & 4400 & 3850 & 3850 & 4033 \\
\hline 4. & Seed + treatment & 4301 & 4547 & 4589 & 4479 \\
\hline 5. & Manure + Fertilizer & 1354 & 1708 & 1819 & 1627 \\
\hline 6. & Plant protection & 1684 & 1638 & 1648 & 1657 \\
\hline 7. & Irrigation charges & 0 & 0 & 0 & $\mathbf{0}$ \\
\hline 8. & Other costs & 152 & 189 & 392 & 244 \\
\hline 9. & Interest on working capital & 324 & 343 & 361 & 343 \\
\hline 10. & Depreciation & 2382 & 1870 & 1477 & 1910 \\
\hline \multirow[t]{2}{*}{11.} & Land revenue & 53 & 85 & 107 & 82 \\
\hline & Cost- $A_{1}$ & 18300 & 18781 & 19294 & 18792 \\
\hline \multirow[t]{2}{*}{12.} & Interest on fixed capital & 238 & 187 & 148 & 191 \\
\hline & Cost- $\mathrm{B}_{1}$ & 18538 & 18968 & 19442 & 18983 \\
\hline \multirow[t]{2}{*}{13.} & Rental value of land & 5000 & 5000 & 5000 & 5000 \\
\hline & Cost- $\mathrm{B}_{2}$ & 23538 & 23968 & 24442 & 23983 \\
\hline \multirow[t]{4}{*}{14.} & Imputed value of family labour & 11000 & 10400 & 9400 & 10267 \\
\hline & Cost $-\mathrm{C}_{1}$ & 29538 & 29368 & 28842 & 29249 \\
\hline & Cost-C 2 & 34538 & 34368 & 33842 & 34249 \\
\hline & Cost- $C_{3}$ & 37992 & 37805 & 37226 & 37674 \\
\hline
\end{tabular}


Table.3 Cost of cultivation of wheat per hectare of existing cropping systems according to their size group (Rs/ha)

\begin{tabular}{|c|c|c|c|c|c|}
\hline \multirow[t]{2}{*}{ S.No. } & \multirow[t]{2}{*}{ Cost practices } & \multicolumn{4}{|c|}{ Size group (Wheat) } \\
\hline & & Small & Medium & Large & Average \\
\hline 1. & Hired human labour & 3400 & 4400 & 4800 & 4200 \\
\hline 2. & Bullock labour & 3150 & 2450 & 2100 & 2567 \\
\hline 3. & Machine power & 2200 & 2200 & 3300 & 2567 \\
\hline 4. & Seed + treatment & 2957 & 3175 & 3302 & 3145 \\
\hline 5. & Manure + Fertilizer & 1791 & 2276 & 2479 & 2182 \\
\hline 6. & Plant protection & 895 & 1240 & 1505 & 1213 \\
\hline 7. & Irrigation charges & 1083 & 1464 & 1599 & 1382 \\
\hline 8. & Other costs & 270 & 211 & 237 & 239 \\
\hline 9. & Interest on working capital & 328 & 363 & 403 & 365 \\
\hline 10. & Depreciation & 2382 & 1870 & 1477 & 1910 \\
\hline \multirow[t]{2}{*}{11.} & Land revenue & 53 & 85 & 107 & 82 \\
\hline & Cost- $A_{1}$ & 18509 & 19734 & 21309 & 19851 \\
\hline \multirow[t]{2}{*}{12.} & Interest on fixed capital & 238 & 187 & 148 & 191 \\
\hline & Cost- $\mathrm{B}_{1}$ & 18747 & 19921 & 21457 & 20042 \\
\hline \multirow[t]{2}{*}{13.} & Rental value of land & 5000 & 5000 & 5000 & 5000 \\
\hline & Cost- $B_{2}$ & 23747 & 24921 & 26457 & 25042 \\
\hline \multirow[t]{4}{*}{14.} & Imputed value of family labour & 9800 & 9000 & 9000 & 9267 \\
\hline & Cost- $\mathrm{C}_{1}$ & 28547 & 28921 & 30457 & 29308 \\
\hline & Cost- $\mathrm{C}_{2}$ & 33547 & 33921 & 35457 & 34308 \\
\hline & Cost- $C_{3}$ & 36902 & 37313 & 39003 & 37739 \\
\hline
\end{tabular}


Table.4 Cost of cultivation of gram per hectare of existing cropping systems according to their size group (Rs/ha)

\begin{tabular}{|c|c|c|c|c|c|}
\hline \multirow[t]{2}{*}{ S.No. } & \multirow[t]{2}{*}{ Cost practices } & \multicolumn{4}{|c|}{ Size group (Gram) } \\
\hline & & Small & Medium & Large & Average \\
\hline 1. & Hired human labour & 400 & 2200 & 3200 & 1933 \\
\hline 2. & Bullock labour & 1750 & 2100 & 1750 & 1867 \\
\hline 3. & Machine power & 2200 & 2750 & 3300 & 2750 \\
\hline 4. & Seed + treatment & 4263 & 4630 & 4955 & 4616 \\
\hline 5. & Manure + Fertilizer & 1491 & 2062 & 2148 & 1900 \\
\hline 6. & Plant protection & 1355 & 1621 & 1783 & 1586 \\
\hline 7. & Irrigation charges & 592 & 735 & 787 & 705 \\
\hline 8. & Other costs & 686 & 1154 & 1199 & 1013 \\
\hline 9. & Interest on working capital & 265 & 359 & 398 & 341 \\
\hline 10. & Depreciation & 2382 & 1870 & 1477 & 1910 \\
\hline \multirow[t]{2}{*}{11.} & Land revenue & 53 & 85 & 107 & 82 \\
\hline & Cost- $A_{1}$ & 15437 & 19566 & 21104 & 18702 \\
\hline \multirow[t]{2}{*}{12.} & Interest on fixed capital & 238 & 187 & 148 & 191 \\
\hline & Cost- $\mathrm{B}_{1}$ & 15675 & 19753 & 21252 & 18893 \\
\hline \multirow[t]{2}{*}{13.} & Rental value of land & 5000 & 5000 & 5000 & 5000 \\
\hline & Cost- $\mathrm{B}_{2}$ & 20675 & 24753 & 26252 & 23893 \\
\hline \multirow[t]{4}{*}{14.} & Imputed value of family labour & 10600 & 9200 & 8400 & 9400 \\
\hline & Cost- $\mathrm{C}_{1}$ & 26275 & 28953 & 29652 & 28293 \\
\hline & Cost- $\mathrm{C}_{2}$ & 31275 & 33953 & 34652 & 33293 \\
\hline & Cost- $\mathrm{C}_{3}$ & 34403 & 37349 & 38118 & 36623 \\
\hline
\end{tabular}


Table.5 Cost of cultivation of different cropping systems (Rs./ha)

\begin{tabular}{|c|c|c|c|c|}
\hline S.No. & Cost particulars & $\begin{array}{c}\text { Soybean } \\
\text { and wheat }\end{array}$ & $\begin{array}{c}\text { Soybean } \\
\text { and Gram }\end{array}$ & $\begin{array}{c}\text { Over }( \pm) \text { to } \\
\text { Soybean-gram }\end{array}$ \\
\hline 1. & Hired human labour & 7333 & 5066 & +2267 \\
\hline 2. & Bullock labour & 3850 & 3150 & +700 \\
\hline 3. & Machine power & 6600 & 6783 & -183 \\
\hline 4. & Seed + treatment & 7624 & 9095 & -1471 \\
\hline 5. & Manure + Fertilizer & 3809 & 3527 & +282 \\
\hline 6. & Plant protection & 2870 & 3243 & -373 \\
\hline 7. & Irrigation charges & 1382 & 705 & +677 \\
\hline 8. & Other costs & 483 & 1257 & -774 \\
\hline 9. & Interest on working capital & 708 & 684 & +24 \\
\hline 10. & Depreciation & 3820 & 3820 & $\mathbf{0}$ \\
\hline \multirow[t]{2}{*}{11.} & Land revenue & 164 & 164 & $\mathbf{0}$ \\
\hline & Cost- $\mathrm{A}_{1}$ & 38643 & 37494 & +1149 \\
\hline \multirow[t]{2}{*}{12.} & Interest on fixed capital & 382 & 382 & $\mathbf{0}$ \\
\hline & Cost- $\mathrm{B}_{1}$ & 39025 & 37876 & +1149 \\
\hline \multirow[t]{2}{*}{13.} & Rental value of land & 10000 & 10000 & $\mathbf{0}$ \\
\hline & Cost- $\mathrm{B}_{2}$ & 49025 & 47876 & +1149 \\
\hline \multirow[t]{4}{*}{14.} & Imputed value of family labour & 19534 & 19667 & -133 \\
\hline & Cost- $\mathrm{C}_{1}$ & 58557 & 57542 & +1015 \\
\hline & Cost- $\mathrm{C}_{2}$ & 68557 & 67542 & +1015 \\
\hline & Cost- $\mathrm{C}_{3}$ & 75413 & 74297 & +1116 \\
\hline
\end{tabular}


In nut shell, on the basis of data analysis on cost of cultivation of different cropping system, it can be concluded that the overall cost of cultivation on per hectare basis of the soybean-wheat cropping system was found to be higher.

Cost $\mathrm{C}_{3}$ incurred in soybean-wheat cropping system was found to be Rs.75413 per hectare. On the other hand, the cost $\mathrm{C}_{3}$ incurred in soybean-gram cropping system was found to be Rs.74297 per hectare. It shows that Cost $\mathrm{C}_{3}$ was higher Rs.1116 per hectare in soybean-wheat cultivation over soybean-gram cultivation Similar finding were reported by Jat, Ram Niwas (2010).

\section{References}

Ahmed and Tanveer (2006). An economic analysis of paddy dased farming systems in Southern Karnataka -A case study of Mandya District. M.Sc. (Agri.) Thesis, submitted to University of Agricultural Sciences, Dharwad.
Biradar and Rajkumar B. (2007). Economics of redgram based cropping systems in Bidar district. M.Sc. (Agri.) Thesis, (Unpublished), University of Agricultural Sciences, Dharwad.

Chauhan,P. (2008). Economic options of different cropping systems of Nimar Valley in Madhya Pradesh. M.Sc. $(A g)$ Thesis. R.A.K. College of Agriculture Sehore.

Jat, Ram Niwas (2010). Economic Viability of different cropping pattern prevailing in Dewas district of Madhya Pradesh. M.Sc. (Ag.) Thesis Submitted to the Rajmata Vijayaraje Scindia Krishi Vishwa Vidyalaya, Gwalior.

Pandey, Pradyumna Raj; Pandey, Hemprabha and Nakagawa, Mitsuhiro (2009). Assessment of rice and maize based cropping systems for rural livelihood improvement in Nepal. The Journal of Agriculture and Environment. 10:5764.

\section{How to cite this article:}

Veena Rathore, Harkesh kumar Balai and Jain, S.K. 2018. To Analyze the Cost Structure of Different Cropping System in Indore (M. P.) India. Int.J.Curr.Microbiol.App.Sci. 7(07): 30893098. doi: https://doi.org/10.20546/ijcmas.2018.707.360 